\title{
Applying Principles of Equity and Certainty in Taxing E- Commerce: A Case Study of Indonesia
}

\author{
Erwin Harinurdin* \\ Finance and Banking Laboratory, Vocational Education Program, Universitas Indonesia \\ *Email: eharinurdin@gmail.com
}

\begin{abstract}
E-commerce transactions can be completed quickly and efficiently anytime and anyplace using the Internet. That characteristic creates problems in applying a transparent and fair tax regulation. The Organization for Economic Co-operation and Development addresses four types of e-commerce transactions: online marketplaces, online retailers, classified ads, and daily deals. Indonesia has adopted its specifications in setting tax laws. The purpose of this research is to explain and describe the legal certainty and fairness of the e-commerce tax policy in Indonesia. It explains that taxation should be equitable and indifferent between e-commerce and conventional transactions. Taxes must be certain and simple so that taxpayers can anticipate tax consequences of transactions and businesses can base decisions on economic rather than tax considerations. Taxpayers in identical situations making identical transactions should be taxed identically. Potential for tax evasion should be minimized.
\end{abstract}

Keywords: tax, e-commerce, equity and certainty, JEL Classification: E62, E65, H25, H26

\section{Introduction}

People everywhere would agree with the proverb "Nothing is certain except death and taxes." However, the evolution of electronic commerce (e-commerce) challenges that adage (Downer, 2016). Developed economies among the Organization for Economic Co-operation and Development (OECD) have adopted comprehensive measures to tax e-commerce income and sales within their borders.

E-commerce can be transacted quickly anytime and anywhere over the Internet. That characteristic complicates applying clear and fair tax regulations. New Zealand, for example, is stepping up enforcement after realizing it is losing significant revenue from e-commerce and digital transactions (Agrawal, 2017). We examine and apply each of these considerations to taxation of e-commerce (Downer, 2016).

Economics literature examines extensively whether to apply taxes at points of origin or destination (Keen et al., 2005). It is unclear where intangible services such as financial, legal, and telecommunication services are consumed (Hellerstein \& Gillis, 2010), and the case for destination taxation is strong on production efficiency grounds. Recent European Union reforms suggest policymakers agree (Keen \& Hellerstein, 2010). Preferential ecommerce taxation is harder to justify when high-income consumers buy heavily via e-commerce (Zodrow, 2006).

Indonesia is among the world's highest-growing economies, and its middle class is the fastest-growing in Southeast Asia. Its modern society of Internet users favors e-commerce. Indonesia is fertile ground for business, especially retailers, for whom its large high-income population constitutes a fat market. Also, traffic congestion in nearly all major Indonesian cities is a boon for e-commerce. E-commerce is flexible as it allows buyers and traders to make any sales and purchases at a time and place of their convenience, and thus it is favored by the modern society of Internet users. Although there has been no empirical research, growth of e-commerce is directly proportional to the decline in congestion in major Indonesian cities.

E-commerce makes collecting direct and indirect taxes a problem. Direct taxation is difficult because ecommerce occurs online between customers whose governments are unaware of it. In addition, conventional businesses have a physical presence (property or agents) within a country (Cooper, 2004), that is unnecessary for e-commerce. Indirect taxes are those imposed on consumer goods alongside value-added tax (VAT). China should consider e-commerce models and adopt a phased policy to encourage its tax base in ways that honor the principles of efficient and just taxation (Dong et al., 2009).

Detecting taxable transactions is particularly difficult when e-commerce crosses national borders. A conventional overseas company opening in Indonesia is taxed on all its business activities. Tax revenues are lost when transactions are unknown to tax authorities in the seller's and buyer's countries. Inefficient taxes and inability to enforce them may retard productivity (Meharia, 2012). State tax should be certain, uniform, and administrable (Hellerstein, 1997). 
A few resulting obstacles and problems were found to be faced because of e-commerce. The first problem was that e-commerce businesses were not permanent establishments (PEs), i.e., they did not have a physical presence, agent, or property within a country (Cooper, 2004). However, with the character and nature of ecommerce, the need to open branches is no longer necessary. International companies are free to market their products in various countries including Indonesia.

Another difficulty is determining which countries may tax e-commerce income. It is difficult to trace the identity of parties doing business. Contrastingly, noting that one Internet transaction might involve several countries, Li (2009) argues that double taxation may present serious consequences as the corporation can freely move an e-commerce business to a tax haven without moving employees. Tax laws should be simple, neutral, and impose minimal compliance burdens (Meharia, 2012).

\section{Research methods}

We employed the post-positivist method of Cresswell and Cresswell (2013) to examine how Indonesia could honor the principles of justice and certainty when taxing e-commerce. Post-positivism entails consulting theory for guidance in formulating problems, objectives, and benefits of research, and then acquiring data to be analyzed. Data then are classified according to prominent theoretical themes to seek patterns.

To examine Indonesia's e-commerce policy we collected qualitative non-numerical data from in-depth interviews, reports, books, articles, and visual media (photographs, drawings, film) To find revealing patterns in descriptive words we applied Nauman's (2003) narrative method to analyze the data. We then triangulated the data by comparing the primary data and secondary data sources with the structure suggested the theory used in this study.

\section{Discussion}

Conventional trading and e-commerce involve supplier transactions with consumers, but e-commerce digitizes them. For tax purposes it is necessary to define types of products transacted through e-commerce. Differing definitions of intangible goods and services create uncertain tax treatment of overseas companies and potential for tax evasion and smuggling. Similar definitions of e-commerce products enable parties to comply with tax obligations and support e-commerce.

E-commerce adds dimensions other than enforceability to the complexities of global taxation. The most troublesome currently is territorial jurisdiction. Basu (2007) calls transboundary transactions the most problematic historically, adding, "the disconnection between the geographical basics of the modern tax system on the one hand and the character of the e-commerce region on the other, is at the heart of the challenge that ecommerce gives a new face to taxation."

To appreciate the impact of e-commerce, we must ask why states impose taxes and user charges. Their goal is to maintain neutrality, fairness, and simplicity that promote economic activity. Most countries' tax policies observe the framework of Adam Smith, who identifies their most important attributes as certainty, equality, economic efficiency, and ease of payment (Downer, 2016).

The USA is the first country to establish tax policy governing e-commerce and digital transactions (Dong et al., 2009). On July 1, 1997, the government issued a global framework indicating that all governments should encourage e-commerce and suggesting an Internet-free zone (Dong et al., 2009).

Many companies transfer operations to low-tax jurisdictions to minimize taxes. On December 4, 2007, the EU issued a new VAT act that taxes transactions in countries where they occur to discourage e-commerce companies from establishing offices in low-tax states. However, tax problems caused by e-commerce grow increasingly serious. In 1999, India declared that computerized purchases of Indian goods by American companies will be regarded as royalties paid in India and subject to Indian tax withholding (Dong et al., 2009).

Notwithstanding differences in tax policy, India, US, and EU authorities emphasize the principle of neutrality. That is, first, taxes should not disrupt production or influence consumption and investment. Second, taxation should not cause losses or expenses other than those imposed by the tax. Observing the principle of neutral taxation implies that tax policies should not prevent e-commerce from becoming a consensus.

OECD countries in October 1998 pioneered a discussion of e-commerce taxation at the Ministerial Conference on Electronic Commerce in Ottawa, Canada. The agenda included taxpayer services, tax administration (including need for identification and information), tax collection and control, consumption taxes, and cooperative tax arrangements. The Committee of Fiscal Affairs is working to clarify tax aspects of ecommerce and has published conditions for tax frameworks. The primary responsibility of free market governance is to assure tax policies are simple, effective, and enforceable. Inefficient taxes and impeded enforcement hamper productivity (Priyanka, 2012). 
The fundamental principle of tax policy is that taxes be economical, equitable, and neutral. A related principle is certainty. All tax obligations must be definite and not arbitrary because all taxpayers will cause the system to be managed the same (Downer, 2016). According to Hellerstein (1997), experts agree that taxation must be convinced, uniform, and administrable. Uncertainty induces sub-optimal behavior and diminishes the integrity of the current tax systems worldwide.

Permanent establishments hold a special position in Indonesia's tax system because taxation of permanent establishments is somewhat different from taxing citizens generally. Also, tax treaties determine whether a source country may tax earnings of companies domiciled abroad. The term "permanent establishment" appeared in Indonesian taxation following enactment of Law No. 7 of 1983 on Income Taxes, on January 1, 1984 (P3B). P3B defines it as a set place where firms wholly or partially conduct business. This kind of permanent establishment is often called an asset-type establishment.

Provisions concerning permanent establishments in tax agreements are important. Besides determining the right of a source country to tax earnings of a company in a partner country, it regulates taxation of business profits by permanent establishments. The definition of permanent establishment is subject to interpretation under respective tax treaties, and it may differ from treaty to treaty. In general, treaties define permanent establishments as places where an overseas company conducts all or part of its business. The existence of a permanent establishment requires two conditions: (a) there must be an identifiable place of business and (b) a foreign company must partly or wholly conduct business there.

Indonesia taxes permanent establishments based on the period applicable to each P3B. If requirements for a permanent establishment in Indonesia are met, the firm's revenues are taxable in Indonesia and subject to withholding. If not, earnings may not be taxable in Indonesia. The power to tax devolves upon the treaty partner of the foreign taxpayer.

Parties engaged in e-commerce might have no conventional physical presence-i.e., an office, agent, or property in the state (Cooper, 2004). However, the location of a server may constitute a permanent establishment. States must determine whether a seller's Internet service provider is its agent and whether its website constitutes a permanent establishment.

E-commerce in Indonesia raises issues about the legal aspects of trading online. Among other problems, the traditional legal system applies the principle of jurisdiction to transactions and contracts. E-commerce presents a problem assigning a jurisdiction to transactions. That and related issues in contract law must be established regionally and internationally, given the borderless and transnational nature of cyberspace.

A contract is an agreement between parties to conduct commercial transactions. To be considered valid, contracts for traditional commercial transactions must be paper-based. E-commerce contracts are paperless and the relevant documents are digital. Verbal agreements can be legal and binding but hard to defend when challenged.

Transactions between private parties, invoices, cover letters, and other documents need not be in writing. Nevertheless, many European tax authorities require written invoices and accounting documents. Tax authorities accept computerized accounting records if their countries' computer systems accommodate requirements specified by the tax authority. The contractual legality of e-commerce transactions is still debated. Some call for improving the legal principles in conventional contracts, such as the time and place of the agreement.

Consumers determine that the viability of e-commerce, and consumer protection is a major factor in its success. Ascertaining that online sellers actually exist is a difficulty that lends itself to fraud.

Neutrality is foremost among Smith's principles that Indonesia should apply to cross-border e-commerce. Taxes should be equitable and indifferent between conventional and e-commerce transactions. Businesses should base decisions on economic rather than tax considerations, and taxpayers in identical situations undertaking identical transactions should be taxed at identically. Tax systems should be sufficiently dynamic to follow developments in technology and trade.

\section{Conclusion}

Indonesia lacks a comprehensive system to tax and monitor e-commerce. Comprehensive systems have mechanisms to supervise transactions, dedicated units, and protocols against tax evasion. Other countries seem better prepared to tax e-commerce. Indonesia's government must honor the principles of justice and legal certainty in taxing e-commerce. Upgraded tax policies that follow general and specific principles are needed to support e-commerce.

\section{Acknowledgment}

I thank the director and my friends at the Finance and Banking Laboratory of the Vocational Education Program at Universitas Indonesia. 


\section{References}

Agrawal, D. R., \& Fox, W. F. (2017). Taxes in an e-commerce generation. International Tax and Public Finance, 24(5), 903926.

Cooper, A. (2003). Electronic commerce: The taxing effect of not assessing internet sales. Journal of State Taxation, 22(4), 84-92.

Creswell, J. W., \& Creswell, J. W. (2013). Qualitative inquiry \& research design: Choosing among five approaches. Los Angeles: SAGE Publications.

Downer, P. (2016). Taxation of electronic commerce (e-comm): Examination of Canadian government tax policies and directives application of Adam Smith's canons of taxation. Journal of Financial Management \& Analysis, 29(1), 114. Retrieved from https://remote-lib.ui.ac.id:2078/docview/1836947238?accountid=17242

David, R., \& William, F. (2016). Taxes in an electronic-commerce generation. International Tax and Public Finance. New York: Springer Science Business Media.

Liu, D., Chen, W., \& Gao, S. W. (2009). Gradual tax policies for China's e-commerce based on mode classification, International Joint Conference on Artificial Intelligence.

Hellerstein, W. (1997). Transaction taxes and e-commerce: Designing state taxes that works in an interstate environment, National Tax Journal, 50(3), 593-606.

Hellerstein, W., \& Gillis, T. H. (2010). The value added tax in the European Union. Tax Notes, 127, 461-471.

Keen, M., Lahiri, S., \& Raimondos-Møller, P. (2002). Tax principles and tax harmonization under imperfect competition: A cautionary example. European Economic Review, 46(8), 1559-1568.

Keen, M., \& Hellerstein, W. (2010). Interjurisdictional issues in the design of a VAT. Tax Law Review, 63(2), 359-408.

Li, J. (1999). Rethinking Canada's source rules in the age of e-commerce-Parts 1 and 2, Canadian Tax Journal, 5-6.

Priyanka, M. (2012). Under the title electronic-commerce and taxation: Past, present and future. Journal of Accounting Research and Audit Practices, 11(4).

Nauman, W. L. (2003). Social Research Methods: Qualitative and Quantitative approaches, Fifth Edition. Boston: Allyn and Bacon.

Zodrow, G. R. (2006). Optimal commodity taxation of traditional and e-commerce. National Tax Journal, 59, 7-31. 